species, Pronuba maculata, Prodoxus marginatus, $P$. cinerius, $P$. anescens and $P$. intirmedius), are described, and the paper concludes with remarks which point to these diffent Yucca Iloths as admirable illustrations of the derivative origin of species.

\section{THE WYANDOT'TES.}

\author{
Bi MIJor J. IV. Powli.L.
}

The Indians now known as the Wyandottes, were first found on the lower St. Lawrence. Subsequently they inhabited a narrow district of country on the shores of Lake Huton, and were known as the Hurons; later they lived in Mlichigan about Detroit ; then in Ohio in what is known as IV yandutte county : from (hio they were moved to Kansas and placed on a reservation : and from Kansas to the Indian Territory. In their wanderings trom point to point, as they were driven from advancing civilization, a few of their number were left behind, so that the Wyandottes are scattered frum the lower St. Lawrence to the Indian Territory along the route of their migration. These Indians call themselves Wundat; the etymology of the word is not known. In their social organization four units are recognized-the family, the gens, the phratry and the tribe. The tamily. as tite term is here used, is nearly synonymous with household. It is composed of the persons who occupy one lodge, or, in their permanent wigwams, one section of a communal dwelling. The head of the family is a woman. The gens is an organized body of consanguineal kindred in the female line. "The woman carries the gens," is the formulated statement by which a Wyandotte expresses the idea that descent is in the female line. Fach gens has the name of some animal-the torm of such animal being its tutelar god. Lip to the time when the tribe left Uhio, eleven gentes were recognized as follows: Deer, Bear, llighland Turtle (striped), Mighland Turtle (black), Mlud Turtle, Smooth large Turtle, liawk, Beaver, Wolf, Sea Snake, Porcupine. In speaking of an individual he is said to be a Wolf, a Bear, or Deer, as the case may be, meaning thercby that he belongs to that gens; but in speaking of the body of people comprising a gens they are said to be relatives of the IV ulf, the Bear, or the Weer, as the case may be.

There are four phatries in the tribe-the three gentes, Bear, Deer and striped Turtle constituting the first; the Ilighland Turtle, Black Turtle and Smowth Large Turtle the stcond; the llawk, Beaver and Wolf the third; and the Se:a-snake and Porcupine the fourth. The eleven gentes as four p!ratries constitute the tribe.

The covil government inheres in a system of councils and chicfs. In each gens there is a council composed of four women. These four women councilors select a chief of the gens from its male members; that is, from their brothers and sons. This gentile chief is the head of the gentile council. The council of the tribe is composed of the agrerrenatted enentile councils. The tribal council, therefore, is composed one-tifth of men and four-fifths of women.

The govermment of the Wyindottes, with the social organization upen which is is batsed, allonds a lepicall example of

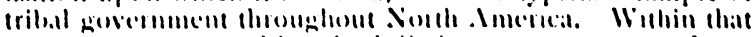

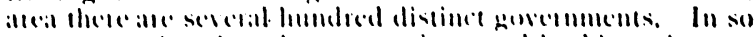

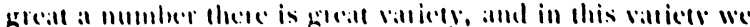

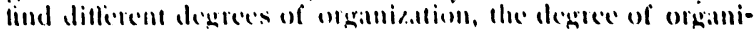
vation being determined by the dillerentiattion of the funce. tions of govermment and the correlative specializaltion of organic elements.

\section{A SIMIPLE DEVICE FOR P'ROJECTING THE VI- BRATIONS OF LIQUID FIL.IS IVITHOUT A LENS.}

Br H. S. CinilikT, A. M., Professor of Physics and Chenistry, Northwestern Livicrsity, Evanston, Ill.

This instrument is designed to project upon the screen the vibrations of a tilm of soapy water produced by the voice or by an oryan pipe. It might be called the self-projecting phoncidosiope. It difters from Sedley 'Taylor's phoneidoscope in three particulars : tirst, the vibrations are commu- nicated to the film through the agency of a mouthpiece and a ferrotype diaphragm ; second, the vibrations are projected on a screen; third, the film is employed to project itself without a lens.

It consists of a wooden tube, having a telcphone mouthpiece at one end and expanding into a large funnel at the vther, the funnel being of metal. In the side of the cube a stop-cock is inserted. A film is obtained in the open end of the funnel and a little air is then blown through the stopcock. This distends the film slightly, causing it to act as a convex nirror. It is then placed in at beam of sunlight and reflects it at the proper angle. C pon singing a note at the mouthpiece a sharply defined system of waves is projected. Photographs of these have been taken. Caps fiting into the funnel and provided with a square or triangular open. ing, are also employed to give filnis of different shape.

\section{THE LAN(IUAGES (IF THE IRUQUOIS.}

$$
\text { lBr Ilks. E. A. SMITH. }
$$

The language of each nation represerts its thought. If these thoughts have remained unrecorded, it is from the language itself that they must be obtained by tracing out the origin, history and meaning of its words. Each word has its histury, which it can be made to reveal by tracing out the origin, history and their most hidden secrets, and the thoughts, customs and beliefs of the originator be read as truthfully as if recorded by the historian's pen. For "words unaided cannot lie:" twenty words in Tuscarora represent supernatural beings. Does this leave a doubt as ts the tendency of their minds? The Tuscarora word for burial ground signifies "placed in the ground in a sitting posture," proving that some time in the past such was their method of burial. The very structure of the Indian languages, where the words are so self-explaining, affords unlimited scope to the etymologist in his search into word history. There are two distinct periods in the modern his. tory of the Iroquois. The inundation of new ideas on the advent of the white man introduced almost a new vocabulary, differing according to the ideas of the observers. For instance, the horse when first seen by the Senecas was drawing logs, hence was called a log drawer. Another tribe saw it carrying packs, and terined it pack-carricr. The Tuscaroras adopted the Fnglish word and term it ha. hath. It is quite remarkable that so few words have been borrowed from the English. And these have becone so Indianized by prefixes and appendages or changes in their vowel sounds as to be scarely recognizable. Among them are: U-ts-oats: S-t-i tar-cider: Ila-hass-horse; Vi-nigair-vincgar; Qui-tair-Peter; Ta-wait-David; T ju-rus -Julius: Nay-yak-it-ando-jacket. Last!y was-tun for Boston, adding to this the plural sulfix ha-kah, a term which in English might be interpreted itis. We have then Was-tun-ha-kah, or Bostonites, which in the Iroquois is the general tcrm for Americans or the whole American nation. This almost supernatural intuition of the Indian mind crystallizes, I do not doubt, the opinion also and belief of at least $250,(.00)$ pale faces residing in the metropolis of Massichusciss. (1) the length of some of incorporattire words, which sometimes contain rerb. sub. ject. object. andective or prepensition. I would remark that the examples generally given it enceloppedias and works on langulge ate almost entelely linglish Indian. That is, a missionarg perhaps, transliting a portion of the Bible, finds some abstract word entirely beyond the comprehension of the Indian nind: he therefore takes Webster's definition of the word and translates that into the Indian in the form of one word until it has the appearance of the heading to a German railway time-table, the words consisting somctimes of forty letters and eleven or twelve syllables. The longest word thus Anglo-Indianized with which I have met is the Mohawk word for stove polish, the word itself being as indicative of the ingenuity of the inventor as the polish itself. It consisted of a glowing description of all the excellencies of said stove polish, which it required filty-eight letters to express. The abstract nouns, represented as being absent from many of the Indian languages, are found in the Tuscarora, such as life, death, love, hate. An interesting feature of the language also might be traced in the prefer- 